\title{
The Effect of Si/Al Ratio to Compressive Strength and Water Absorption of Ferronickel Slag-based Geopolymer

\author{
Mustofa $^{1}$ and Sungging Pintowantoro ${ }^{1}$
}

\begin{abstract}
Geopolymer material is inorganic polymers that are generally synthesized from aluminosilicate materials, such as ferronickel slag. In this study, synthesis of geopolymer material using $\mathrm{NaOH} 7$ molar and $\mathrm{Na}_{2} \mathrm{SiO}_{3}$ solutions with different Si/Al ratio to make paste. Paste is molded in a metal mold with dimensions of $5 \times 5 \times 5 \mathrm{~cm}^{3}$, then released from the mold and heated in an oven at $80{ }^{\circ} \mathrm{C}$ for 24 hours. The specimens that have been heated further left at room temperature for 28 days and then tested for compressive strengthand water absorption. The results indicate a trend compressive strength increases and water absorption decreases with increasing the Si/Al ratio. The optimum condition is obtained when Si/Al ratio is 3.5 .
\end{abstract}

Keywords-ferronikel slag, inorganic polymer, aluminosilicate material.

\section{INTRODUCTION}

Geopolymer is amorphous to semi-crytalline materials that synthesized from materials generally contain $\mathrm{SiO}_{2}$ and $\mathrm{Al}_{2} \mathrm{O}_{3}$ compounds as a source of aluminosilicate. Geopolymers were synthesized by mixing at room temperature or higher (e.g., $90{ }^{\circ} \mathrm{C}$ ) reactive aluminosilicate powder with alkaline activator containing alkali hydroxide, silicate, aluminate, carbonate or sulfate, or a combination thereof.

Geopolymer materials have several advantages including high initial strength, low shrinkage, freeze-thaw resistance, resistance to sulfates, corrosion, acid, fire resistance, and resistance to alkali aggregate harmless reactions. When compared with the cement, geopolymer productions required operating low temperatures and energy, low $\mathrm{CO}_{2}$ emissions [1] and the availability of raw materials are still quite a lot. One of the materials that are used as raw materials for the synthesis of geopolymer is ferronickel slag [2] [3] [4]. Ferronickel slag is an industrial by-product generated during smelting to ferronickel used in the manufacture of stainless steel and nickel alloys [5]. Main reason for the selection of ferronickel slag as raw material geopolymer synthesis is it has the high content of silica and alumina components, where those components have an important role in the geopolymerization reaction.

Synthesis of geopolymer typically include (a) pretreatment mechanical of raw material aluminosilicate solid (crushing and grinding), (b) the preparation of the initial liquid silicate alkali phase, (c) mixing of the solid and liquid phases, (d) the moulding paste, (e) curing at low to moderate temperature $\left(40-80^{\circ} \mathrm{C}\right)$ for several hours, and (f) setting in the environment [6]. This study was conducted to determine the effect of $\mathrm{Si} / \mathrm{Al}$ ratio on the properties of geopolymer produced include compressive strength and water absorption.

\section{METHOD}

\section{A. Material}

Geopolymer samples were prepared from ferronickel slag that crushed up to size $\leq 70 \mu \mathrm{m}$. Chemical and mineralogical analyses of slag are performed by EDX and XRD analysis, as given in Table 1 . Based on Table 1 are known that have a higher silica content than the calcium oxide, magnesium oxide and alumina. Some minerals were detected in a ferronickel slag is augite $\left[(\mathrm{Ca}, \mathrm{Na})(\mathrm{Mg}, \mathrm{Fe}, \mathrm{Al}, \mathrm{Ti})(\mathrm{Si}, \mathrm{Al})_{2} \mathrm{O}_{6}\right]$, forsterite $\left(\mathrm{Mg}_{2} \mathrm{SiO}_{4}\right)$, and pyrope $\left(\mathrm{Mg}_{3} \mathrm{Al}_{2}\left(\mathrm{SiO}_{4}\right)_{3}\right)$.

\section{B. Synthesis of Geopolymer Material}

Synthesis of geopolymer material was prepared through four stages. First, making the activator solution by mixing of $\mathrm{NaOH} 7$ molar and $\mathrm{Na}_{2} \mathrm{SiO}_{3}$ solutions with ratio is 2.5 , and then left it for 24 hours. Second, mixing the activator solution and ferronickel slag powder with a mass ratio of the slag and the activator solution ( $\mathrm{S} / \mathrm{L}$ ratio) was 5.4 while stirring process is carried out to make a paste. Third, paste was molded into metal molds with dimensions of $5 \times 5 \times 5 \mathrm{~cm}^{3}$, and then released from the mold. Finally, the curing process is divided into two stages, namely heating in an oven at $80{ }^{\circ} \mathrm{C}$ for 24 hours and curing at room temperature up to 28 days for further hardening.

\section{Analysis and Tests}

The mineralogical and microstructure studies of the slag-based geopolymers were performed by means of XRay Diffractometry (XRD), Fourier-Transform Infrared Spectroscopy (FTIR) and Scanning Electron Microscopy (SEM) analysis.

The geopolymers properties studied in this work include compressive strength and water absorption. Compressive strength was measured on a universal testing machine of the Concrete and Building Material Laboratories, Department of Civil Engineering using cubic specimens with dimensions $5 \times 5 \times 5 \mathrm{~cm}^{3}$ according to the ASTM C109 standard test. Three specimens of each experiment were tested and the average compressive strength was reported as the result. The water absorption was determined according to the ASTM C1403 standard test 


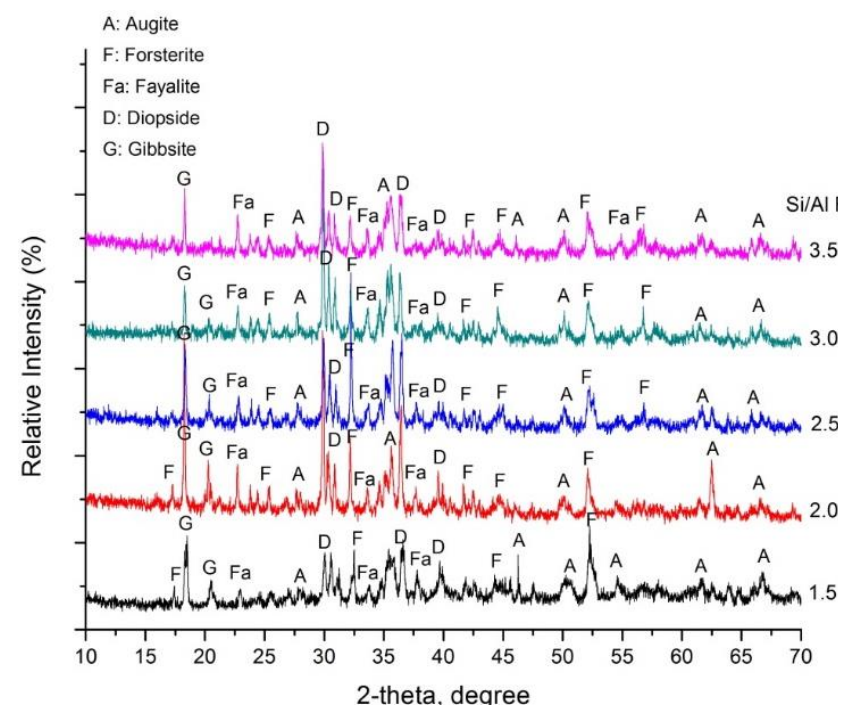

Figure 1. XRD Patterns of Geopolymer

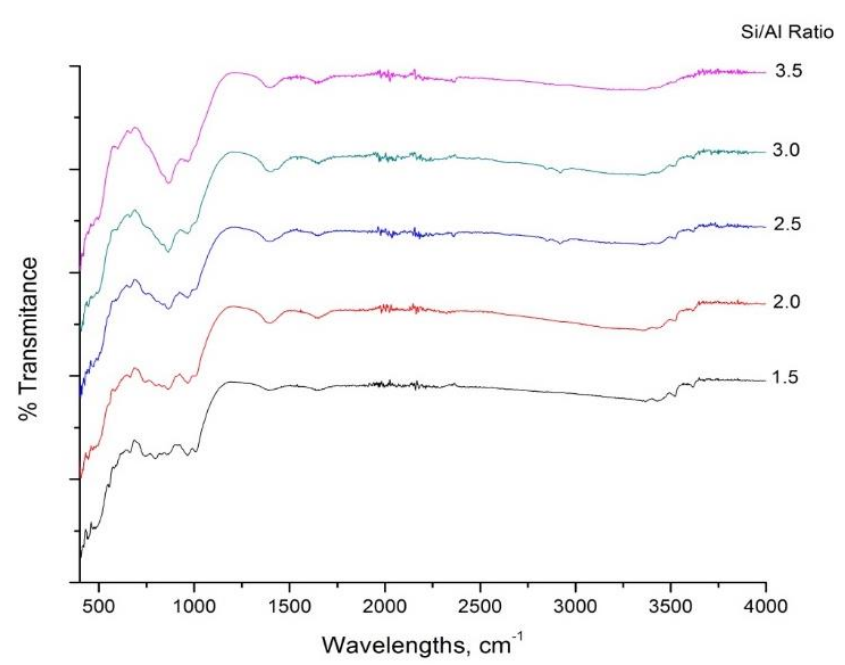

Figure 2. FTIR Spectra of Geopolymer

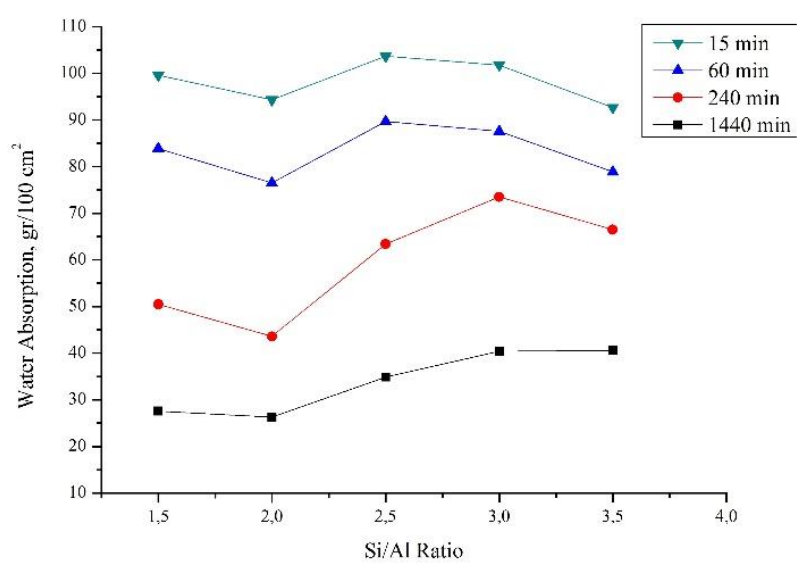

Figure 3. Water Absorption of Geopolymer.

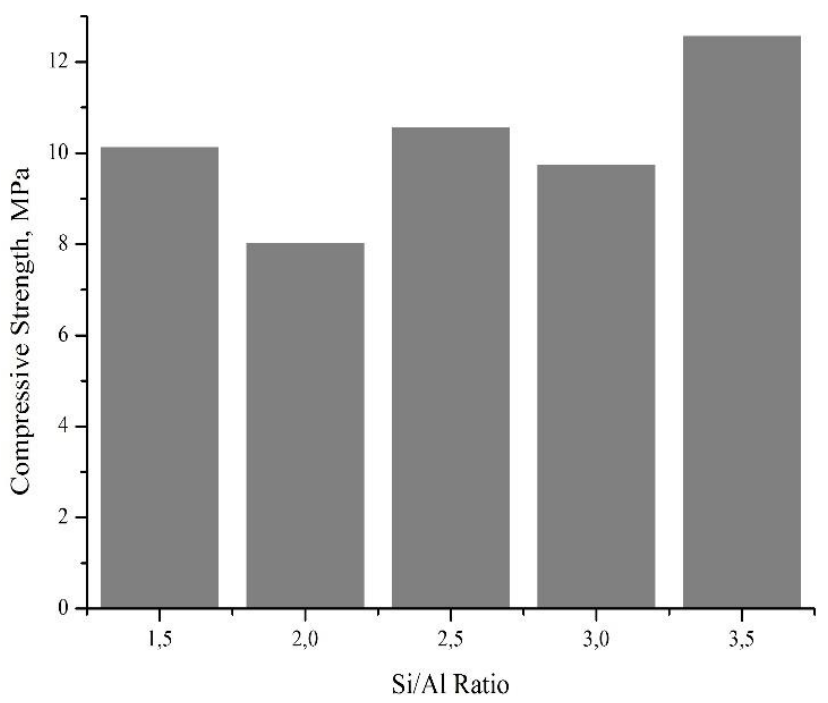

Figure 4. Compressive Strength of Geopolymer

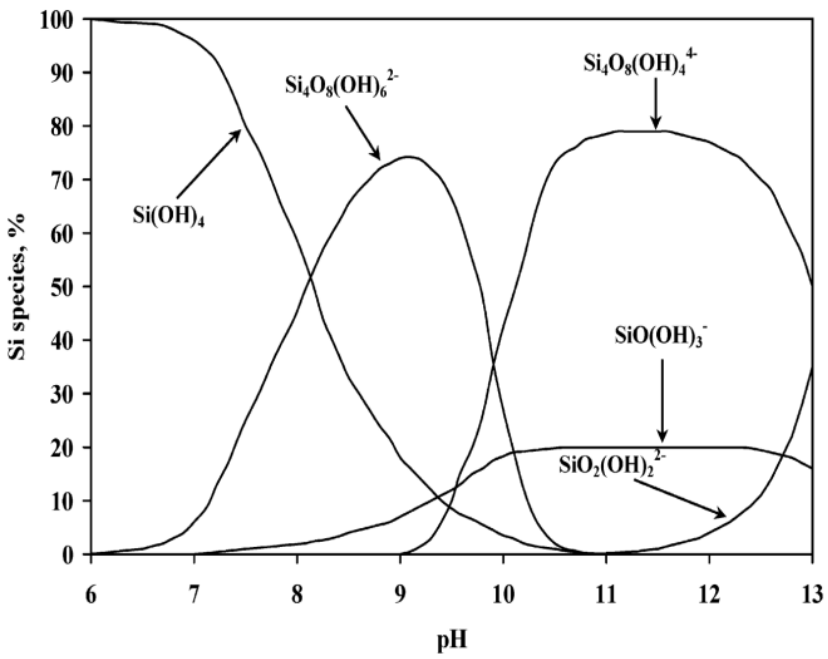

Figure 5. Speciation Diagram of Si in Aqueous Solution [8]

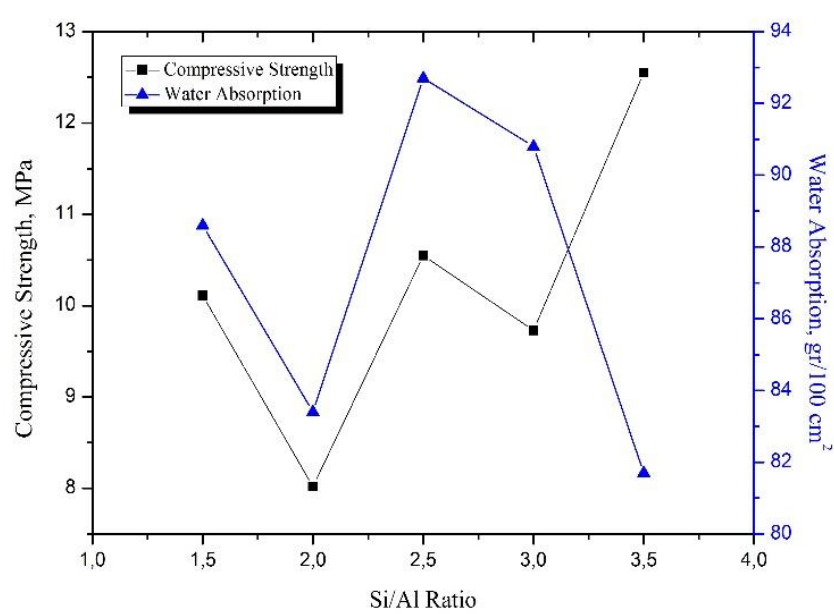

Figure 6. Compressive Strength versus Water Absorption (after immersion for 24 hours) of Geopolymer 


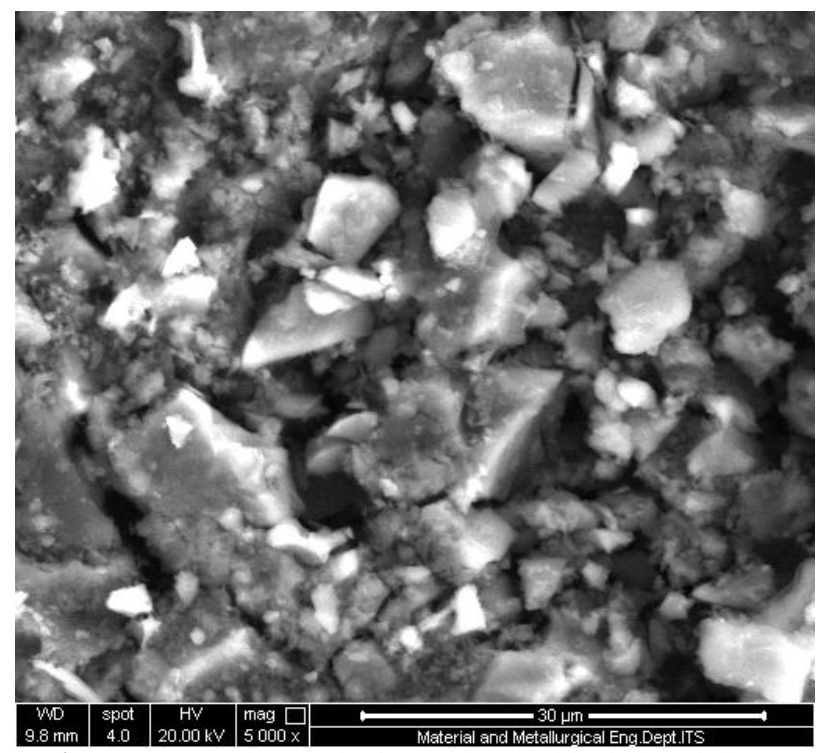

Figure 7. SEM Micrograph of Geopolymer with $\mathrm{Si} / \mathrm{Al}$ Ratio is 1.5

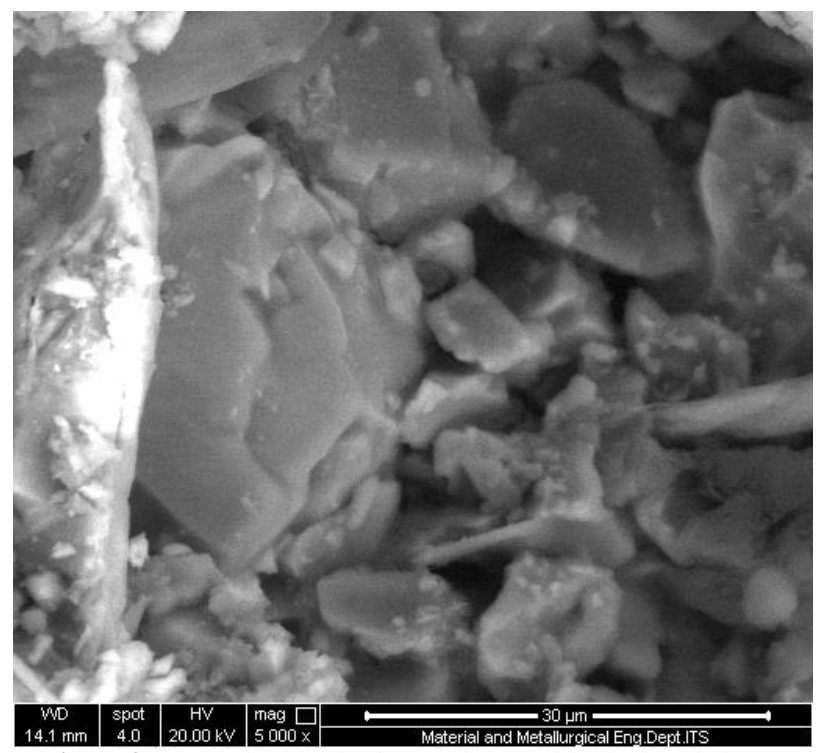

Figure 8. SEM Micrograph of Geopolymer with $\mathrm{Si} / \mathrm{Al}$ Ratio is 2.5

TABLE 1.

CHEMICAL COMPOSITIONS OF FERRONICKEL SLAG

\begin{tabular}{ccc}
\hline \hline No & Compounds & Compositions (\% wt) \\
\hline 1 & $\mathrm{SiO}_{2}$ & 43.08 \\
2 & $\mathrm{Al}_{2} \mathrm{O}_{3}$ & 9.13 \\
3 & $\mathrm{FeO}$ & 8.43 \\
4 & $\mathrm{MgO}$ & 18.67 \\
5 & $\mathrm{CaO}$ & 20.69 \\
\hline \hline
\end{tabular}

TABLE 2

MINERAL COMPOSITIONS OF FERRONICKEL SLAG-BASED GEOPOLYMER

\begin{tabular}{|c|c|c|c|c|}
\hline No & Group & Mineral Name & Formula & Reference Code \\
\hline \multirow[t]{2}{*}{1} & Pyroxene & Augite & $(\mathrm{Ca}, \mathrm{Na})(\mathrm{Mg}, \mathrm{Fe}, \mathrm{Al}, \mathrm{Ti})(\mathrm{Si}, \mathrm{Al})_{2} \mathrm{O}_{6}$ & 01-088-0849 \\
\hline & & Diopside & $\mathrm{CaMgSi}_{2} \mathrm{O}_{6}$ & 01-083-1821 \\
\hline \multirow[t]{2}{*}{2} & Olivine & Forsterite & $\mathrm{Mg}_{2} \mathrm{SiO}_{4}$ & $00-001-1290$ \\
\hline & & Fayalite & $\mathrm{Fe}_{2} \mathrm{SiO}_{4}$ & 01-071-1668 \\
\hline 3 & & Gibbsite & $\mathrm{Al}(\mathrm{OH})_{3}$ & 01-074-1775 \\
\hline
\end{tabular}

\section{RESULTS AND DISCUSSION}

\section{A. Mineralogical and Structure of Geopolymer} Material

Mineralogical transformation that occurs during the geopolymerization process of ferronickel slag and minerals contained in each of the geopolymer material can be seen in Figure 1 and Table 2. Generally, the peaks produced has a sharpness decreases with increasing $\mathrm{Si} / \mathrm{Al}$ ratio, especially at $2 \theta=17.25,20.42$ and 52.11. This indicates that the geopolymerization process produce amorphous phase structure of the aluminosilicate.
The new peak is formed for all products geopolymer at $2 \theta=18.34$ and 20.42 is characteristic of gibbsite. This is confirmed by previous studies, where in the alkaline solution, $\mathrm{Al}(\mathrm{OH})_{3}$ experienced the dissolution to forming aluminate species [7]. The presence of gibbsite at $2 \theta=$ 20.42 has a peak decreases with increasing $\mathrm{Si} / \mathrm{Al}$ ratio. This characteristic can be attributed to the formation of geopolymer structure is more complex because of the increased concentration of $\mathrm{Si}$ so that more aluminate species is used for the dissolution of silicate. Characteristic peaks at $2 \theta<20^{\circ}$ is a phenomenon polycondensation that lasted geopolymerization of liquid 
phase aluminosilicate as the portion dissolution of the amorphous phase in ferronickel slag.

Results of FTIR analysis can be seen in Figure 2, shows absorption bands at wavelengths between $400-4000 \mathrm{~cm}^{-1}$. The new peaks were generated occurs at wavelengths range 400-500, 700-1100, 1300-1750 and 3300-3700 cm 1 . Broadly, the FTIR spectra are divided into two ranges, namely $370-1300 \mathrm{~cm}^{-1}$ related to vibration mode of $\mathrm{Si}-\mathrm{O}$ Si unit and $1600-4000 \mathrm{~cm}^{-1}$ related to the vibration mode of water [6]. This reflects the fact that the range of 1600$4000 \mathrm{~cm}^{-1}$ geopolymer product containing free water absorbed from the environment and water molecules bound in the structure of geopolymer network of the crystallization process and the absorption of the reaction product [8] [9] [10]. Peaks at $1300-1600 \mathrm{~cm}^{-1}$ related to the absorption band which is owned by carbonate units [11] [12] [13] [14].

The peaks of the range of $400-1200 \mathrm{~cm}^{-1}$ indicates the structure of $\mathrm{Si}-\mathrm{O}-\mathrm{X}(\mathrm{X}=\mathrm{Si}, \mathrm{Al})$ in geopolymer system. At a wavelength around 768-1200 $\mathrm{cm}^{-1}$ shows the geopolymerization process [6]. The smaller the ratio of $\mathrm{Si} / \mathrm{Al}$ leads to the formation of new peaks in the structure of geopolymer. New peak began to look at the ratio of $\mathrm{Si} / \mathrm{Al}=3$, especialy at a wavelength around $1009.63 \mathrm{~cm}^{-1}$ to more sharply with the smaller ratio of $\mathrm{Si} / \mathrm{Al}$. This relates to the asymmetric stretching vibration of $\mathrm{Si}-\mathrm{O}$ units in $\mathrm{SiO}_{4}$ tetrahedral structure in the aluminosilicate. asymmetric stretching vibration and shifting tape reveals early dissolution of the solid material into a strong alkaline solution and the establishment of new products during geopolymerization. The new products generated from these events is an amorphous aluminosilicate phase [2] [13]. Absorption band at $664.34 \mathrm{~cm}^{-1}$ relating to the incorporation of $\mathrm{AlO}_{4}$ in the aluminosilicate caused by the formation of a new phase of amorphous zeolites [2].

\section{B. Effect of Si/Al Ratio to Water Absorption}

The purpose of the water absorption test is to determine how easily water flows into the geopolymer material. Water absorption is a very important parameter in the manufacture of geopolymer for showing permeability and rate of reaction of the geopolymer. The low water absorption will be low permeability. Generally, high rate of geopolymerization leads to geopolymer matrix has a pore and low permeability [15]. Based on the results obtained is known that the water absorption tends to increase with the increase of immersion time and the ratio of $\mathrm{Si} / \mathrm{Al}$ (Figure 3). Geopolymer with a $\mathrm{Si} / \mathrm{Al}$ ratio $=2$ has the lowest water absorption. Besides that, the water absorption decreasing in 240 and 1440 minutes of time with increasing $\mathrm{Si} / \mathrm{Al}$ ratio from 2.5 to 3.5 .

In this study specimens heated in an oven for 24 hours at $\pm 112{ }^{\circ} \mathrm{C}$. The purpose of this method is to obtain a mass constant of specimen. That is, the test specimen is completely dry in order for water testing occurs efficiently. The values obtained water absorption is still relatively very high. One of the factors that influence it is the level of dryness of the specimen. The specimens were dried at room temperature have a lower water absorption than the specimens are dried in the oven until a constant mass. Specimens are dried under saturated humidity after 28 days at $20^{\circ} \mathrm{C}$ have a lower water absorption than the specimens are dried at $105^{\circ} \mathrm{C}[16]$.
Another study describes the influence of pressure in the manufacture of geopolymer to water absorption. Increased water absorption with the increased pressure causes higher amounts of $\mathrm{NaOH}$ solution is squeezed out [17]. In such conditions, the geopolymerization reaction blocked so geopolymer gel formed slightly and then produce a high porosity of the geopolymer matrix. In other words, the higher geopolymerization process was inhibited so that the structure of geopolymer produced less homogeneous (Figure 7) as a result of the slag that is not involved in the reaction. After 1440 minute immersion, water absorption of geopolymer is decrease with increasing of $\mathrm{Si} / \mathrm{Al}$ ratio. This results show that the increasing of $\mathrm{Si} / \mathrm{Al}$ ratio role on the forming homogeneous microstructure so that decrease water absorption.

\section{Effect of Si/Al Ratio to Compressive Strength}

Figure 4 shows the compressive strength increasing with increasing ratio of $\mathrm{Si} / \mathrm{Al}$ although there are deviations in $\mathrm{Si} / \mathrm{Al}$ ratio $=2.0$ and 3.0, respectively. However, they have a tendency compressive strength increase with increase of $\mathrm{Si} / \mathrm{Al}$ ratio too. These results were confirmed by previous studies that an increase in the compressive strength with increasing concentration of $\mathrm{Si}$ although the increase was not linear [18].

Hardening process of specimens occurs because geopolymerization reactions that include condensation reactions that depend on the type of aluminate and silicate produce silicate and aluminate monomers. Silicate and aluminate monomers produced as a hydrolysis reaction or dissolution of $\mathrm{Al}^{3+}$ and $\mathrm{Si}^{4+}$ components form $\left[\mathrm{Al}(\mathrm{OH})_{4}\right]^{-}$, $\left[\mathrm{SiO}(\mathrm{OH})_{3}\right]^{-}$and $\left[\mathrm{SiO}_{2}(\mathrm{OH})_{2}\right]^{2-}$. This process is influenced by the concentration of $\mathrm{NaOH}$ solution is used as the activator solution. At high concentrations of $\mathrm{NaOH}(8$ molar), the early stages of the condensation reaction starting from a stable oligomer formation as a dimer result of condensation between $\left[\mathrm{Al}(\mathrm{OH})_{4}\right]^{-}$and $\left[\mathrm{SiO}_{2}(\mathrm{OH})_{2}\right]^{2-}$ according to Equation 1. The resulting structure of Equation 1 is a stable dimer structures within the framework of polisialat $(\mathrm{Si}: \mathrm{Al}=1)$.

$$
\left[\mathrm{SiO}_{2}(\mathrm{OH})_{2}\right]^{2-}+\left[\mathrm{Al}(\mathrm{OH})_{4}\right]^{-} \rightarrow\left[(\mathrm{OH})_{3} \mathrm{Al}-\mathrm{O}-\mathrm{SiO}_{2}(\mathrm{OH})\right]^{3-}+\mathrm{H}_{2} \mathrm{O}
$$

The low compressive strength is one factor that the delayed of geopolymerization process for low $\mathrm{Si} / \mathrm{Al}$ ratio. In this condition, known simply occurred early high dissolution of $\mathrm{Al}$. Low concentrations of $\mathrm{Si}$ ( $\mathrm{Si} / \mathrm{Al}$ ratio is low) yielding a poly(sialate) structure [7] as a result of the replacement of $\mathrm{Si}$ by $\mathrm{Al}$. That is, at the loww $\mathrm{Si} / \mathrm{Al}$ ratio most of the aluminum is present in the form of $\left[\mathrm{Al}(\mathrm{OH})_{4}\right]^{-}$ monomer. The high $\left[\mathrm{Al}(\mathrm{OH})_{4}\right]^{-}$monomer causes high alkalinity so that the reaction product in Equation 1 tends to react with $\left[\mathrm{Al}(\mathrm{OH})_{4}\right]^{-}$condenses further aluminosilicate trimer [19]. Although this type of dimer and trimer produced were dominant, but in these conditions a higher polymerization is difficult that disrupts the hardening process of geopolymer. The high aluminate is then easily formed bond is the bond of Si-O-Al weaker than the bond $\mathrm{Si}-\mathrm{O}-\mathrm{Si}$ in geopolymer system. Theoretically, the bond between $\mathrm{Si}-\mathrm{O}-\mathrm{Si}$ is stronger than the $\mathrm{Si}-\mathrm{O}-\mathrm{Al}$ and $\mathrm{Al}-\mathrm{O}-$ $\mathrm{Al}$, which means that the strength increases with increasing $\mathrm{Si} / \mathrm{Al}$ ratio.

The low ratio of $\mathrm{Si} / \mathrm{Al}$ affects the loss of compressive strength associated with the low $\left[\mathrm{SiO}(\mathrm{OH})_{3}\right]^{-}$structure to 
form the larger gepolymer structure than the $\left[\mathrm{SiO}_{2}(\mathrm{OH})_{2}\right]^{2-}$ structure as a result of the high aluminate in the system. Equilibrium and stability of both types of silicate structure depends on the $\mathrm{pH}[20]$. In speciation diagram of $\mathrm{Si}$ (Figure 5), the structure of $\left[\mathrm{Si}(\mathrm{OH})_{3}\right]^{-}$is more stable than the structure of $\left[\mathrm{SiO}_{2}(\mathrm{OH})_{2}\right]^{2-}$ on high alkaline condition.

Increasing the ratio of $\mathrm{Si} / \mathrm{Al}$ is useful to provide an silicate extra component in the form $\left[\mathrm{SiO}(\mathrm{OH})_{3}\right]^{-}$ monomer according to the reaction in Equation 2 [16]. Availability $\left[\mathrm{SiO}(\mathrm{OH})_{3}\right]^{-}$monomer complete the process of condensation reaction (Equation 3 ) with $\left[\mathrm{Al}(\mathrm{OH})_{4}\right]^{-}$and self-polymerization between groups silicate produced in the generation of silicate oligomer.

$$
\begin{aligned}
& {\left[\mathrm{SiO}_{2}(\mathrm{OH})_{2}\right]^{2-}+\mathrm{H}^{+} \rightarrow\left[\mathrm{SiO}(\mathrm{OH})_{3}\right]^{-}} \\
& {\left[\mathrm{Al}(\mathrm{OH})_{4}\right]^{-}+\left[\mathrm{SiO}(\mathrm{OH})_{3}\right]^{-} \rightarrow\left[(\mathrm{OH})_{3} \mathrm{Al}-\mathrm{O}-\mathrm{SiO}(\mathrm{OH})_{2}\right]^{2-}+\mathrm{H}_{2} \mathrm{O}}
\end{aligned}
$$

Further condensation process between the reaction product (Equation 3) with $\left[\mathrm{SiO}(\mathrm{OH})_{3}\right]^{-}$to form a more stable products until all the $\left[\mathrm{Al}(\mathrm{OH})_{4}\right]^{-}$monomer used in the reaction. In a system with a high concentration of $\mathrm{Si}$ ( $\mathrm{Si} / \mathrm{Al}$ ratio is high), the condensation process begins with the formation of oligomer silicates. Finally, the formation of a polymer network is composed [19].

The reaction continues until leads to the formation geopolymer structures of poly(sialate-siloxo), -Si-O-Al$\mathrm{O}-\mathrm{Si}-\mathrm{O}-$ or poly(sialate-disiloxo), -Si-O-Al-O-Si. The higher concentration of dissolved silicate source plays a role in increasing the amount of $\mathrm{Si}-\mathrm{O}-\mathrm{Si}$ bonds and compressive strength [21] [22]. In addition, the formation of geopolymer network depends on the concentration of $\left[\mathrm{SiO}(\mathrm{OH})_{3}\right]^{-}$. In the $\mathrm{Si} / \mathrm{Al}$ ratio is low, the silicate monomer that resulted is $\left[\mathrm{SiO}_{2}(\mathrm{OH})_{2}\right]^{2-}$ and $\left[\mathrm{Al}(\mathrm{OH})_{4}\right]^{-}$, where the condensation reaction that occurs between the two tend to form small oligomers, such as dimers and trimers [19]. With increasing $\mathrm{Si} / \mathrm{Al}$ ratio, the concentration of $\left[\mathrm{SiO}(\mathrm{OH})_{3}\right]^{-}$also increased, where the condensation reaction between $\left[\mathrm{SiO}(\mathrm{OH})_{3}\right]^{-}$with $\left[\mathrm{Al}(\mathrm{OH})_{4}\right]^{-}$forming the large oligomers and lead to the establishment of the complex polymer network so that increasing the strength.

\section{Relationship between Water Absorption and Compressive Strength of Geopolymer}

Generally, there is a relationship between water absorption and compressive strength of geopolymer, where the higher the compressive strength indicates that the microstructures produced more homogeneous and dense so that tends to lower water absorption. At a ratio $\mathrm{Si} / \mathrm{Al}=1.5$ to 3.0 , water absorption is directly proportional to the compressive strength of up to 3.5 water absorption is inversely proportional to the compressive strength (Figure 6). Although there are deviations in the ratio Si/Al $=1.5$ to 3.0 , but at the ratio of $\mathrm{Si} / \mathrm{Al}=3.5$ provides information that increases the compressive strength will cause decreases the water absorption as a result of homogeneous geopolymer produced and solid and has a low porosity. The optimum condition is obtained when the geopolymer material has high compressive strength with low water absorption, where the condition is achieved when the geopolymer cement has a ratio of $\mathrm{Si} / \mathrm{Al}=3.5$.

\section{E. SEM Analysis of Geopolymer Material}

Durability of the structure of the construction material in its application is closely dependent on the physicalmechanical properties and its transport, such as permeability and ion diffusivity controlled by microstructural characteristics of hardening to a certain extent of the binder. Porosity and pore size distribution is a vital component of the microstructure of the material. It determines the permeability of binder gel and penetration rate by an aggressive agent [23]. The permeability property with regard to other physical properties, such as water absorption, which is one aspect to be considered in the application, especially in conditions that are susceptible to water. Changes in microstructure and porosity associated with lability of silicate species which control the rate of structural reorganization during geopolymerization, where the structure of $\left[\mathrm{SiO}_{2}(\mathrm{OH})_{2}\right]^{2-}$ more labil than $\left[\mathrm{SiO}(\mathrm{OH})_{3}\right]^{-}$. High lability promote the occurrence of large interconnected porosity as a result of low concentrations of $\mathrm{Si}$ [21].

SEM analysis performed one of which is to determine the microstructure and morphology of geopolymer product, especially regarding an overview of the porosity and size of the particles formed. Increasing the ratio of $\mathrm{Si} / \mathrm{Al}$ contribute in the formation of microstructures that are more compact, dense and homogeneous. Geopolymer material with a ratio $\mathrm{Si} / \mathrm{Al}=2.5$ is more homogeneous than the ratio of $\mathrm{Si} / \mathrm{Al}=1.5$ (Figure 7 and 8 ). This is possibly due to the insoluble particles of slag. The insoluble of particles caused interface bonds with the binder is a sensitive area that reveal failures during the testing of compressive strength [2]. Thus, the higher of ratio $\mathrm{Si} / \mathrm{Al}$ caused the formation of the structure of $\mathrm{Si}-\mathrm{O}$ $\mathrm{Si}$ and silicate species are more stable. This stability is formed by a further geopolymerization process leading to the formation of more complex network and homogeneous of geopolymer thus increasing strength.

\section{CONCLUSION}

There is a tendency of increasing the compressive strength and reduced water absorption by increasing the ratio of $\mathrm{Si} / \mathrm{Al}$. The optimum condition was obtained when the ratio of $\mathrm{Si} / \mathrm{Al}=3.5$. There is a possibility of increased compressive strength with $\mathrm{Si} / \mathrm{Al}$ ratio of more than 3.5.

\section{ACKNOWLEDGMENTS}

The authors would like to thank The Extraction Metallurgy Laboratory of Material and Metallurgical Engineering and The Concrete and Building Material Laboratory of Civil Engineering.

\section{REFERENCES}

[1] J. Davidovits, "Properties of Geopolymer Cements", in Proceedings First International Conference on Alkaline Cements and Concretes, pp.1-19, 1994.

[2] I. Maragkos, I. P. Giannopoulou, and D. Panias, "Synthesis of Ferronickel Slag-based Geopolymers", Minerals Engineering, vol. 22, pp.196-203, 2009

[3] K. Komnitsas, D. Zaharaki, and G. Bartzas, "Effect of Sulphate and Nitrate Anions on Heavy Metal Immobilisation in Ferronickel Slag Geopolymers", Applied Clay Science, vol. 73, pp.103-109, 2013.

[4] N. Lemonis, P. E. Tsakiridis, N. S. Katsiotis, S. Antiohos, D Papageorgiou, M. S. Katsiotis, and M. Beazi-Katsioti, "Hydration Study of Ternary Blended Cements Containing Ferronickel Slag and 
Natural Pozzolan”, Construction and Building Materials,vol. 81, pp.130-139, 2015.

[5] T. Sato, K. Watanabe, A. Ota, M. Aba, and Y. Sakoi, "Influence of Excessive Bleeding on Frost Susceptibility of Concrete Incorporating Ferronickel Slag as Aggregates", in 36th Conference on Our World in Concrete \& Structures. 2011.

[6] D. Dimas, I. Giannopoulou, and D. Panias, "Polymerization in Sodium Silicate Solutions: A Fundamental Process in Geopolymerization Technology", Journal of Material Science, vol. 44, pp.3719-3730, 2009.

[7] M. J. A. Mijarsh, M. A. M. Johari, and Z. A. Ahmad, "Effect of Delay Time and $\mathrm{Na} 2 \mathrm{SiO} 3$ Concentrations on Compressive Strength Development of Geoplymer Mortar Synthesized from TPOFA", Construction and Building Materials, vol. 86, pp.64-74, 2015.

[8] D. Panias, I. Giannopoulou, and T. Perraki, "Effect of Synthesis Parameters on the Mechanical Properties of Fly Ash-based Geopolymers", Colloids and Surfaces, vol. 301, pp.246-254, 2007.

[9] M. B. Ogundiran and S. Kumar, "Synthesis and Characterisation of Geopolymer from Nigerian Clay", Applied Clay Science, vol. 108, pp.173-181, 2015

[10] F. Puertas and A. Fernandez-Jimenez, "Mineralogical and Microstructural Characterisation of Alkali-activated Fly Ash/Slag Pastes", Cement \& Concrete Composites, vol. 25, pp.287-292, 2003.

[11] Z. Zhang, H. Wang, J. L. Provis, F. Bullen, A. Reid, and Y. Zhu, "Quantitative Kinetic and Structural Analysis of Geopolymers. Part 1. The Activation of Metakaolin with Sodium Hidroksida", Thermochemica Acta, vol. 539, pp.23-33, 2012.

[12] S. K. Nath and S. Kumar, "Influence of Iron Making Slags on Strength and Microstructure of Fly Ash Geopolymer", Construction and Building Materials, vol. 38, pp.924-930, 2013.

[13] S. Onisei, Y. Pontikes, T. van Gerven, G. N. Angelopoulos, T. Velea, V. Predica, and P. Moldovan, "Synthesis of Inorganic Polymers Using Fly Ash and Primary Lead Slag", Journal of Hazardous Materials, vol. 205-206, pp.101-110, 2012.

[14] S. K. Nath, S. Maitra, S. Mukherjee, and S. Kumar, "Microstructural and Morphological Evolution of Fly Ash Based Geopolymers", Construction and Building Materials, vol. 111, pp.758-765, 2016.

[15] P. W. Ken, M. Ramli, and C. C. Ban, "An Overview on The Influence of Various Factors on The Properties of Geopolymer Concrete Derived from Industrial by-Products", Construction and Building Materials, vol. 77, pp.370-395, 2015.

[16] T. Yang, X. Yao, and Z. Zhang, "Geopolymer Prepared with Highmagnesium Nickel Slag: Characterization of Properties and Microstructure", Construction and Building Materials, vol. 59, pp.188-194, 2014

[17] S. Ahmari, X. Ren, V. Toufigh, and L. Zhang, "Production of Geopolymeric Binder from Blended Waste Concrete Powder and Fly Ash”, Construction and Building Materials, vol. 35, pp.718-729, 2012.

[18] I. Giannopoulou, D. Dimas, I. Maragkos and D. Panias, "Utilization of Metallurgical Solid by-Products for The Development of Inorganic Polymeric Construction Materials", Global NEST Journal, vol. 11, no. 2, pp.127-136, 2009.

[19] L. Weng and K. Sagoe-Crentsil, "Dissolution Processes, Hydrolisis and Condensation Reactions during Geopolymer Synthesis: Part ILow Si/Al Ratio Systems", Journal of Material Science, vol. 42, pp.2997-3006, 2007.

[20] Z. Zhang, J. L. Provis, H. Wang, F. Bullen, and A. Reid, "Quantitative Kinetic and Structural Analysis of Geopolymers, Part 2. Thermodynamics of Sodium Silicate Activation of Metakaolin", Thermochemica Acta, vol. 565, pp.163-171, 2013.

[21] P. Duxson, J. L. Provis, G. C. Lukey, S. W. Mallicot, W. M. Kriven, and J. S. J. van Deventer, "Undestanding the Relationship Between Geopolymer Composition, Microstructure and Mechanical Properties", Colliods and Surfaces A: Physicochemistry Engineering Aspects, vol. 269, pp.47-58, 2005.

[22] C. Lampris, R. Lupo, and C. R. Cheeseman, "Geopolymerisation of Silt generated from Construction and Demolition Waste Washing Plants", Waste Management, vol. 29. pp.368-373, 2009.

[23] A. Hajimohammadi, J. L. Provis, and J. S. J. van Deventer, “Timeresolved and Spatially-resolved Infrared Spectorcopic Observation of Seeded Nucleation Controling Geopolymer Gel Formation", Journal of Colloid and Interface Science, vol. 357, pp.384-392, 2011

[24] Badan Informasi Geospasial, 2015., "Modul Validasi Peta Rencana Tata Ruang. Modul 1 Sumber Data,". Bogor

[25] Badan Informasi Geospasial, 2015.,"Modul Validasi Peta Rencana Tata Ruang. Modul 2 Sebaran Dan Pemilihan Titik,”. Bogor
[26] Badan Informasi Geospasial, 2015., "Modul Validasi Peta Rencana Tata Ruang. Modul 3 Pengukuran GPS,". Bogor

[27] BIG, 2015. "Modul Validasi Peta Rencana Tata Ruang. Modul 4 Orhorektifikasi dan Uji Akurasi,”. Bogor 